\title{
Digital amnesia and the future tourist
}

\section{Chris Greenwood and Matthew Quinn}

\begin{abstract}
Purpose - The purpose of this paper is to examine the phenomenon of digital amnesia and its influence on the future tourist.

Design/methodology/approach - A trend paper based on environmental scanning and speculative future analysis.

Findings - The phenomena of digital amnesia are established. The growth of digital platforms and the consumer's reliance is exponential. The implications for the future tourist in terms of decision making, the influence of marketing messaging and potentially the recall and reimagining of authentic experience will be significant in the future.

Practical implications - Subject to the signals of change, should consumer's reliance on digital platforms for the storing of information and memories continue to grow this has implications on how tourism businesses engage with their customers, influence and inform their marketing and how destinations would be reimagined based on the recall of their visitors.

Originality/value - The trend of digital amnesia is an established and well-documented phenomenon. The development of the trend to consider the implications for the future tourism industry based a growing dependence on digital platforms is the focus of this paper.
\end{abstract}

Keywords Tourism, Trends, Consumer behaviour, Futures, Digital

Paper type Research paper

\section{Signal of change}

Within the modern age, it is with some understatement to say that the internet has generated a paradigm shift in society. Looking exclusively at tourism, the advent of the digital economy has, "according to the WTO, [the internet] revolutionised the distribution of tourism information and sales" (Hojeghan and Esfangareh, 2011). Looking at the penetration of internet use globally in June 2016, around half the world's population were internet users, representing a growth in usage from 2000 to 2016 of 918.3 per cent (Internetworldstats.com, 2016). The distribution of internet usage varies by world region, however, as Table I illustrates all world regions show at least 50 per cent penetration rate of internet users by regional population.

Accompanying the growth of the internet have been technological advancements which have exploited the ubiquity of the network. The most significant mainstream development in recent times has been the digital mobile platform through handsets such as tablets and smartphones. The implication of mobile technology and tourism is increasingly being researched (Wang et al. , 2014; Tussyadiah and Wang, 2014), indeed the search "digital travel trend" will yield around 5.5 million search results. It is therefore safe to assume that the growth of the internet and the adoption of mobile platforms has made a significant impact on societal behaviour, especially in terms of tourism.

\section{Trend indicator}

The specific phenomena which will be presented in this paper relates to the implication to tourism of the observed rise and impact of digital amnesia. Digital Amnesia is defined as:

The experience of forgetting information that you trust to a digital device to store and remember for you (Kaspersky Labs and Opinion Matters, 2015).
Chris Greenwood is a Senior Tourism Insight Manager and Matthew Quinn is a Senior Insight Analyst, both at the Department of Insight, VisitScotland, Edinburgh, UK.

Received 2 November 2016 Accepted 17 November 2016

(C) Chris Greenwood and Matthew Quinn. Published in the Journal of Tourism Futures. This article is published under the Creative Commons Attribution (CC BY 4.0) licence. Anyone may reproduce, distribute, translate and create derivative works of this article (for both commercial and non-commercial purposes), subject to full attribution to the original publication and authors. The full terms of this licence may be seen at http://creativecommons.org/ licences/by/4.0/legalcode

The opinions expressed in this paper are the authors own and do not represent either expressed or implied the policy or position of

VisitScotland, Scottish

Government or associated organisations. 
Table I World internet usage and population statistics, 30 June 2016 - update

\begin{tabular}{|c|c|c|c|c|c|c|}
\hline World regions & $\begin{array}{l}\text { Population } \\
\text { (2016 est.) }\end{array}$ & $\begin{array}{l}\text { Population } \\
\text { of world (\%) }\end{array}$ & $\begin{array}{l}\text { Internet users } \\
\text { (30 June 2016) }\end{array}$ & $\begin{array}{c}\text { Penetration rate } \\
\text { (\% pop.) }\end{array}$ & $\begin{array}{c}\text { Growth } \\
(2000-2016)(\%)\end{array}$ & Users (\%) \\
\hline Asia & $4,052,652,889$ & 55.2 & $1,846,212,654$ & 45.6 & $1,515.2$ & 50.2 \\
\hline Europe & $832,073,224$ & 11.3 & $614,979,903$ & 73.9 & 485.2 & 16.7 \\
\hline Latin America/Caribbean & $626,054,392$ & 8.5 & $384,751,302$ & 61.5 & $2,029.4$ & 10.5 \\
\hline Africa & $1,185,529,578$ & 16.2 & $340,783,342$ & 28.7 & $7,448.8$ & 9.3 \\
\hline North America & $359,492,293$ & 4.9 & $320,067,193$ & 89.0 & 196.1 & 8.7 \\
\hline Middle East & $246,700,900$ & 3.4 & $141,489,765$ & 57.4 & $4,207.4$ & 3.8 \\
\hline Oceania/Australia & $37,590,820$ & 0.5 & $27,540,654$ & 73.3 & 261.4 & 0.8 \\
\hline World total & $7,340,094,096$ & 100.0 & $3,675,824,813$ & 50.1 & 918.3 & 100.0 \\
\hline
\end{tabular}

The term, Digital Amnesia has been in use for several years (Missingham and Hinchliffe, 2005) and consistently relates to the identification of discovery and retention of information resulting in the shift from analogue or hard copy data storage to reliance on digital devices for information storage and recovery.

At the core of Digital Amnesia is the societal shift from individuals remembering and recalling information to reliance of digital devices to store information (such as phone numbers, appointment schedules and so on) and for accessing information for searching. The trust in connected devices to perform the role of information guardian exists in parallel to another phenomenon, the "Google effect" (Kaspersky Labs and Opinion Matters, 2015) where researchers observed that while the retention of information was declining, the recall of where information was stored increased. It therefore reinforces the position that as digital platforms increase in importance, consumers are increasingly prepared to trust technology to store our information so we do not need to remember it but we do know where the information may be obtained should we require it. The growth of smartphones and mobile platforms has contributed to the acceleration of this position in recent years.

\section{Implications and disruptors}

- According to research by the University of Western Ontario, the average human attention span has fallen from 12 to 8 seconds since 2000, or around the time in the growth of mobile communications technology. Separate research by Microsoft found that the ability of humans to multitask has however improved (Watson, 2015).

- "Mobile technology use allows for activities typically associated with pre-trip and post-trip experiences to be enacted on-site. For example, using smartphones, tourists can make informed decisions on trip itineraries (i.e. activities to partake in, attractions to visit, etc.) with the help of location based services" (Tussyadiah and Wang, 2014).

- Digital Amnesia could disrupt tourism experiences through failure of technologies or limited communications infrastructure in the destination visited.

- Should travellers entrust their accommodation name or address to online booking platforms rather than to memory or print, is there the possibility they would be unable to transit from transport hub to destination if they did not have access to their digital platforms?

- Researching destinations will continue to be a pre-trip activity; however, the output of that research may not define a fixed list of activities that will be undertaken in a chosen destination, merely a checklist of suitable ranges of activities from which a short list of destinations can be selected among the other variables required. It would be fluid itineraries which will develop on arrival, as access to local information and social media influence of recommendation could make commitment to activities be determined on the day.

- Smartphone use and adoption, combined with Digital Amnesia suggest future tourism suppliers would need to invest in engaging proximity based content to enlist a short-term decision response. The reaction therefore would be "always on" content marketing, regularly

\begin{tabular}{l|l|l} 
PAGE 74 & JOURNAL OF TOURISM FUTURES & VOL. 3 NO. 12017
\end{tabular} 
updated with continuous investment in technology and research and development to be able to push digital messages to potential customers.

- The contrasting position to the implication of Digital Amnesia would be any potential consumer recoil around hyper-personalised advertising to which the individual loses their sense of self-discovery and adventure within their travel experience. Furthermore, with the commoditisation of identity; where an individual will provide personal details (registering on websites for access to information or entering competitions, for example) for some benefit such as discounts on products, exclusive information, consumers realise the value of their information and therefore may not be prepared to provide profiling information without gaining some benefit.

- Another implication may be that of the dissemination and consumption of information to consumers. As consumers are daily flooded with deals and offers from various marketing streams, it begs the question, how much of this information is retained by the consumer? By developing innovative promotional communications, tourism businesses may be able to offer a more engaging content to potential customers.

\section{Conclusion}

The implications of Digital Amnesia could be a valued opportunity to engage the disengaged. With consumers becoming ever more dependent on technology, tourism businesses may become increasingly technically savvy to gain consumer attention. Which poses the question, why do you need grey matter when you have $4 \mathrm{G}$ or cloud storage?

With the growth of internet and digital connectivity across the globe, consumers are becoming more immersed within their digital devices, and subsequently creating digital lives. This has led to many users now becoming so reliant on their devices, they do not need to remember simple things such as a hotel or restaurant reservation.

So how can tourism businesses capitalise on this issue? The construction of innovative, attention grabbing promotional marketing could be utilised in location service software within smartphone and tablets to alert consumers when they are close to certain attractions or providers. Although there are existing examples of this already within a number business sectors, tourism businesses, especially within areas of high competition, to truly set their selves apart. Advising consumers on potential activities on day trips or short breaks, may also be a lucrative opportunity within this field. As consumers, would normally rely on their technology to search for locations for holidays or things to do, the development of engaging content on tourism products could set businesses apart from competitors.

\section{References}

Hojeghan, S.B. and Esfangareh, A.N. (2011), "Digital economy and tourism impacts, influences and challenges", Procedia - Social and Behavioral Sciences, Vol. 19, pp. 308-16, available at: http://dx.doi.org/ 10.1016/j.sbspro.2011.05.136; www.sciencedirect.com/science/article/pii/S1877042811012511.

Internetworldstats.com (2016), "World internet users statistics and 2016 world population stats", available at: www.internetworldstats.com/stats.htm (accessed 31 October 2016).

Kaspersky Labs and Opinion Matters (2015), "The rise and impact of digital amnesia", available at: https://blog. kaspersky.com/files/2015/06/005-Kaspersky-Digital-Amnesia-19.6.15.pdf (accessed 1 November 2016).

Missingham, R. and Hinchliffe, M. (2005), "Digital Amnesia: challenges of government online”, available at: www.austlii.edu.au/au/journals/inCiteALIA/2005/124.pdf (accessed 1 November 2016).

Tussyadiah, I. and Wang, D. (2014), "Tourists attitudes toward proactive smartphone systems", Journal of Travel Research, Vol. 55 No. 4, pp. 493-508.

Wang, D., Xiang, Z. and Fesenmaier, D. (2014), "Smartphone use in everyday life and travel", Journal of Travel Research, Vol. 55 No. 1, pp. 52-63.

Watson, L. (2015), "Humans have shorter attention span than goldfish, thanks to smartphones", The Telegraph, available at: www.telegraph.co.uk/science/2016/03/12/humans-have-shorter-attention= span-than-goldfish-thanks-to smart/ (accessed 9 May 2016). 


\section{About the authors}

Chris Greenwood is a Senior Tourism Insight Manager at VisitScotland, Scotland's National Tourist Board. Furthermore, the author is also a part-time postgraduate research student at the Glasgow Caledonian University undertaking a PhD examining the nature of National Tourism Policy in Scotland during the first 15 years of devolution. Chris Greenwood is the corresponding author and can be contacted at: Chris.Greenwood@visitscotland.com

Matthew Quinn is a Senior Insight Analyst with VisitScotland's Insight Team, responsible for monitoring and interpreting trends in Scottish Tourism. A graduate of Glasgow Caledonian University, with over five years of tourism research experience, the author has a broad knowledge base, which has supported insight into several arenas from economics to the environment; and has an interest on the drivers of consumer behaviour within the tourism industry.

For instructions on how to order reprints of this article, please visit our website: 